\title{
Correction to: The impact of calcite impurities in clays containing kaolinite on their reactivity in cement after calcination
}

\author{
Franco Zunino $\cdot$ Emmanuelle Boehm-Courjault $\cdot$ Karen Scrivener
}

Published online: 25 March 2021

(C) The Author(s) 2021

\section{Correction to:}

Materials and Structures (2020) 53:44

https://doi.org/10.1617/s11527-020-01478-9

The article "The impact of calcite impurities in clays containing kaolinite on their reactivity in cement after calcination", written by Franco Zunino, Emmanuelle Boehm-Courjault and Karen Scrivener, was originally published electronically on the publisher's internet portal on 16 April 2020 without open access. The copyright of the article changed in February 2021 to $($ C) The Author(s) 2021 and the article is forthwith distributed under the terms of the Creative Commons Attribution 4.0 International License (https:// creativecommons.org/licenses/by/4.0/), which permits use, duplication, adaptation, distribution and reproduction in any medium or format, as long as you give appropriate credit to the original author(s) and the source, provide a link to the Creative Commons license and indicate if changes were made.

Open Access This article is distributed under the terms of the Creative Commons Attribution 4.0 International License (https://creativecommons.org/licenses/by/4.0/), which permits unrestricted use, distribution, and reproduction in any medium, provided you give appropriate credit to the original author(s) and the source, provide a link to the Creative Commons license, and indicate if changes were made.

Publisher's Note Springer Nature remains neutral with regard to jurisdictional claims in published maps and institutional affiliations.
The original article can be found online at https:// doi.org/10.1617/s11527-020-01478-9.

F. Zunino $(\bowtie) \cdot$ E. Boehm-Courjault · K. Scrivener Laboratory of Construction Materials, EPFL STI IMX LMC, Station 12, 1015 Lausanne, Switzerland e-mail: franco.zunino@epfl.ch 